University of Nebraska - Lincoln

DigitalCommons@University of Nebraska - Lincoln

2002

\title{
One New Species and One New Combination in Netechma Razowski (Lepidoptera: Tortricidae: Euliini)
}

John W. Brown

Systematic Entomology Laboratory, Plant Sciences Institute, Agricultural Research Service, U.S. Department of Agriculture, c/o National Museum of Natural History, Washington, DC 20560-0168, jbrown@sel.barc.usda.gov

David Adamski

Systematic Entomology Laboratory, Plant Sciences Institute, Agricultural Research Service, U.S. Department of Agriculture, c/o National Museum of Natural History, Washington, DC 20560-0168

Follow this and additional works at: https://digitalcommons.unl.edu/systentomologyusda

Part of the Entomology Commons

Brown, John W. and Adamski, David, "One New Species and One New Combination in Netechma Razowski (Lepidoptera: Tortricidae: Euliini)" (2002). USDA Systematic Entomology Laboratory. 45.

https://digitalcommons.unl.edu/systentomologyusda/45

This Article is brought to you for free and open access by the Entomology Collections, Miscellaneous at DigitalCommons@University of Nebraska - Lincoln. It has been accepted for inclusion in USDA Systematic Entomology Laboratory by an authorized administrator of DigitalCommons@University of Nebraska - Lincoln. 


\title{
ONE NEW SPECIES AND ONE NEW COMBINATION IN NETECHMA RAZOWSKI (LEPIDOPTERA: TORTRICIDAE: EULIINI)
}

\author{
JoHn W. BRown AND David AdAMSKI \\ Systematic Entomology Laboratory, Plant Sciences Institute, Agricultural Research \\ Service, U.S. Department of Agriculture, c/o National Museum of Natural History, \\ Washington, DC 20560-0168 (E-mail: jbrown@sel.barc.usda.gov)
}

\begin{abstract}
Netechma similis, new species, from Costa Rica, is described and illustrated, and Netechma caesiata (Clarke), new combination, from Venezuela, is redescribed and illustrated. Netechma Razowski belongs to a group of genera in Euliini characterized by one or more sparganothine-like features of the male genitalia, including a spiny transtilla; a long, slender, hooklike uncus; and densely scaled socii. Adults of the two treated species are superficially most similar to species of Icteralaria Razowski, with a forewing that features a broad, dark, medial band on a pale yellow ground color.
\end{abstract}

Key words: Genitalia, Cochylis caesiata, biodiversity, Costa Rica, Venezuela.

Through the efforts of "parataxonomists," scientists, and collaborators associated with the Instituto Nacional de Biodiversidad, Santo Domingo, Costa Rica, and augmented by an independent, NSF-funded project, the Arthropods of La Selva, important collections of the Lepidoptera of Costa Rica have accumulated over the last decade. These collections provide significant insight into tropical biodiversity, particularly for poorly known groups, including those of agricultural importance such as leafroller moths (Tortricidae).

A large portion of the accumulated material is represented by undescribed taxa that illuminate previously unknown relationships among species and provide taxonomic information for the development of a framework of genera into which new species may be placed in the future (e.g., Razowski, 1990, 1992, 1997; Brown, 1998, 1999a, b, c). The genus Netechma Razowski, represented in Costa Rica by at least five described species (including the new species described herein), is restricted to the New World tropics, ranging from Costa Rica to Argentina. As currently defined, the genus, with $N$. technema (Walsingham) as type species, includes 29 species; however, the limits of the genus are poorly defined. Netechma shares some characters with Icteralaria Razowski, but relationships of the two genera are unclear.

The purposes of this paper are to describe one new species and propose one new combination in Netechma: N. similis, new species, from Costa Rica, and N. caesiata (Clarke), new combination, from Venezuela. Netechma caesiata, known only from females, was described in Cochylis (Cochylini) (Clarke, 1968) on the basis of superficial similarities with members of that genus, and its generic and tribal assignments have remained obscure (Powell et al., 1995). However, the discovery of both males and females of a closely related, undescribed congener in Costa Rica provides evidence for the transfer of that species to Netechma.

This article is a U.S. government work, and is not subject to copyright in the United States. 


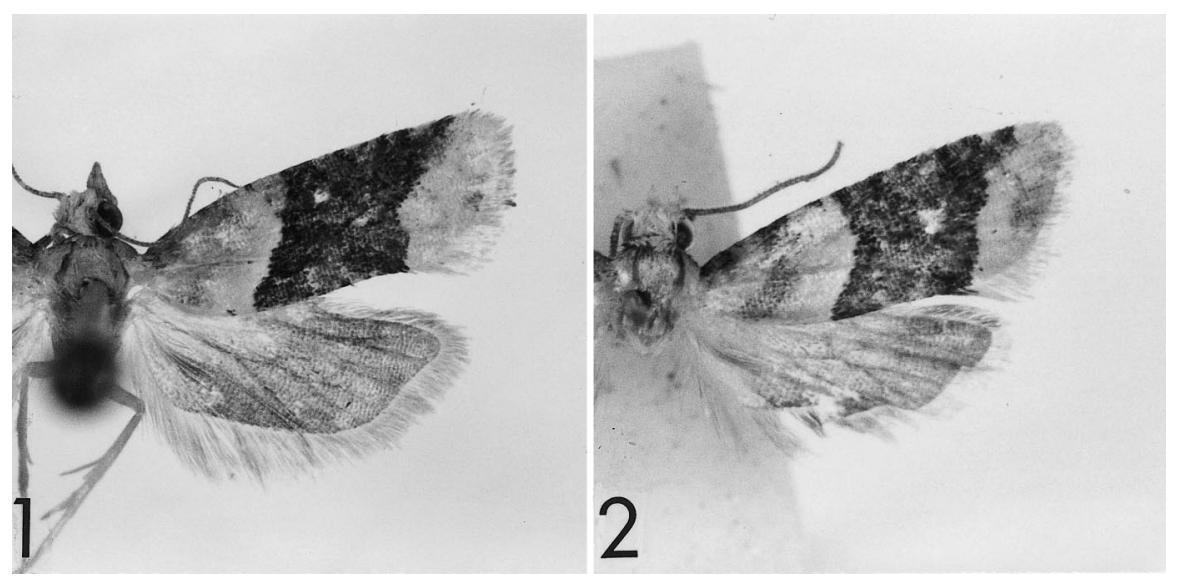

Figs. 1-2. Adults of Netechma. 1. N. caesiata (female); 2. N. similis (female).

\section{MATERIALS AND METHODS}

We examined 21 pinned specimens of adult moths obtained from the following institutions: Instituto Nactional de Biodiversidad (INBio), Santo Domingo de Herédia, Costa Rica, and National Museum of Natural History (USNM), Smithsonian Institution, Washington, D.C., U.S.A. Specimens were sorted by geographic location and then examined for differences in male and female genitalia. Genitalia and wing preparations of representative individuals were made following the methods summarized in Brown and Powell (2000). Illustrations of wing venation and genitalia were drawn with the aid of a Jena Pictoval $\mathbb{C}$ microprojector. Unless indicated otherwise, illustrations are of a single preparation. Descriptions are composite, based on all available specimens. Forewing measurements were made with a transparent millimeter ruler under low power of a Leica MZ12@ dissecting microscope, and estimated to the nearest one-tenth millimeter. Terminology for wing venation and genitalia structures follows Horak (1984). Abbreviations are as follows: FW = forewing; HW = hindwing; $\mathrm{DC}=$ discal cell; $\mathrm{N}=$ number of individuals examined; $\overline{\mathrm{x}}$ $=$ mean; ca. $=$ about (approximately).

SYSTEMATICS

Netechma similis, new species

Figs. 2, 4, 5

Diagnosis. Adults of both $N$. similis and $N$. caesiata are moderately small, with a forewing that features a broad, dark, medial band on a buff to pale yellow ground color quite distinct from other congeners, but nearly identical to that of Icteralaria idiochroma Razowski and Icteralaria incusa (Meyrick). Superficially, the forewing band of I. idiochroma and I. incusa is a v-shaped trapezoid (see Clarke 1958), whereas that of $N$. similis and $N$. caesiata is roughly a parallelogram. The two species, similis and caesiata, are assigned to Netechma on the basis of the unusual, 

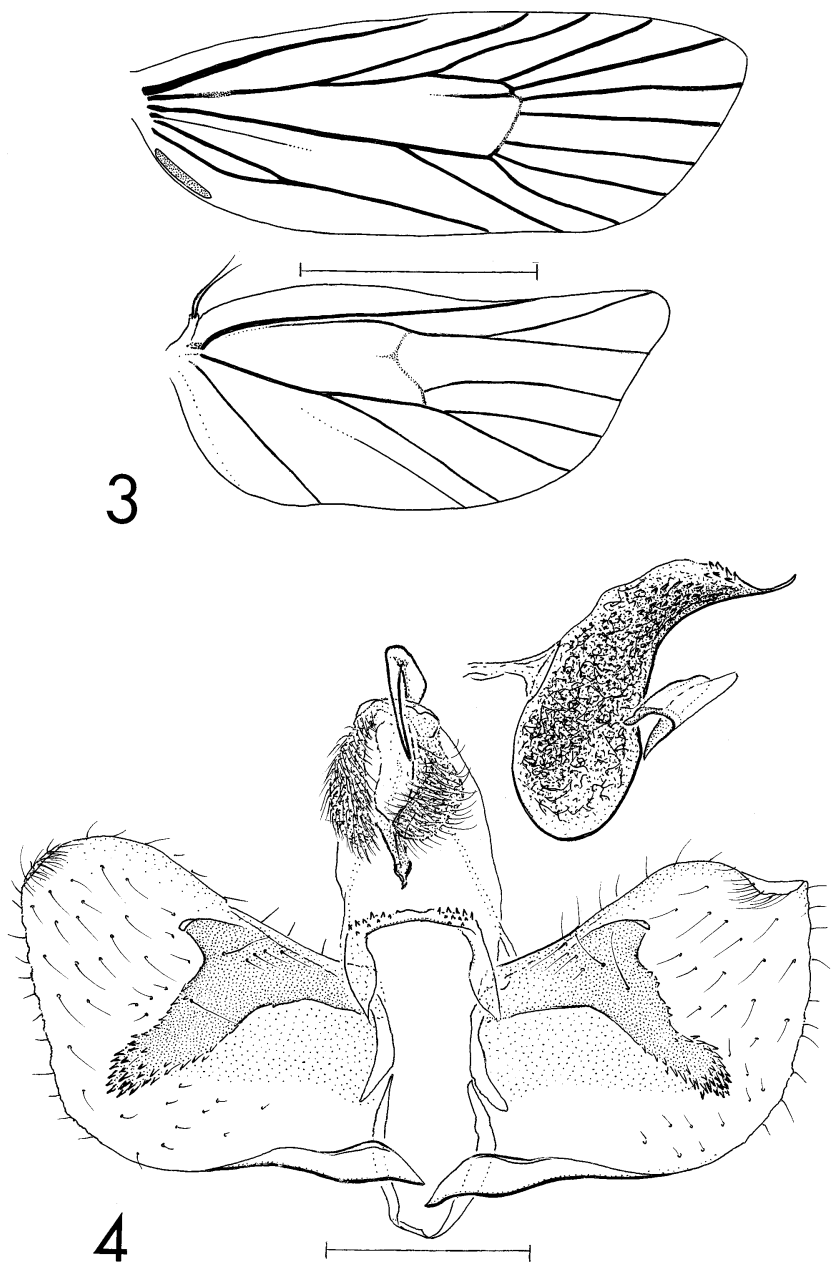

Figs. 3-4. Wing venation and genitalia of Netechma. 3. N. caesiata, female, wing venation $($ scale bar $=2.0 \mathrm{~mm}) ; 4$. N. similis, male, genitalia with valvae spread and aedeagus removed (scale bar $=0.25 \mathrm{~mm}$ ).

long, trough-like signum in the female genitalia, which appears to represent a synapomorphy for a species group within Netechma that includes $N$. similis, N. caesiata, $N$. technema (the type species of the genus), and a few other undescribed species. Males of both Icteralaria and Netechma lack the foreleg hairpencil (Brown, 1990), and both sexes in both genera lack ocelli. Netechma similis is nearly indistinguishable superficially from $N$. caesiata, but the basal portion of the forewing usually is more strongly marked with darker scales in $N$. similis, particularly along the costa. The female genitalia of the two can be separated by the shape of the spiny process 


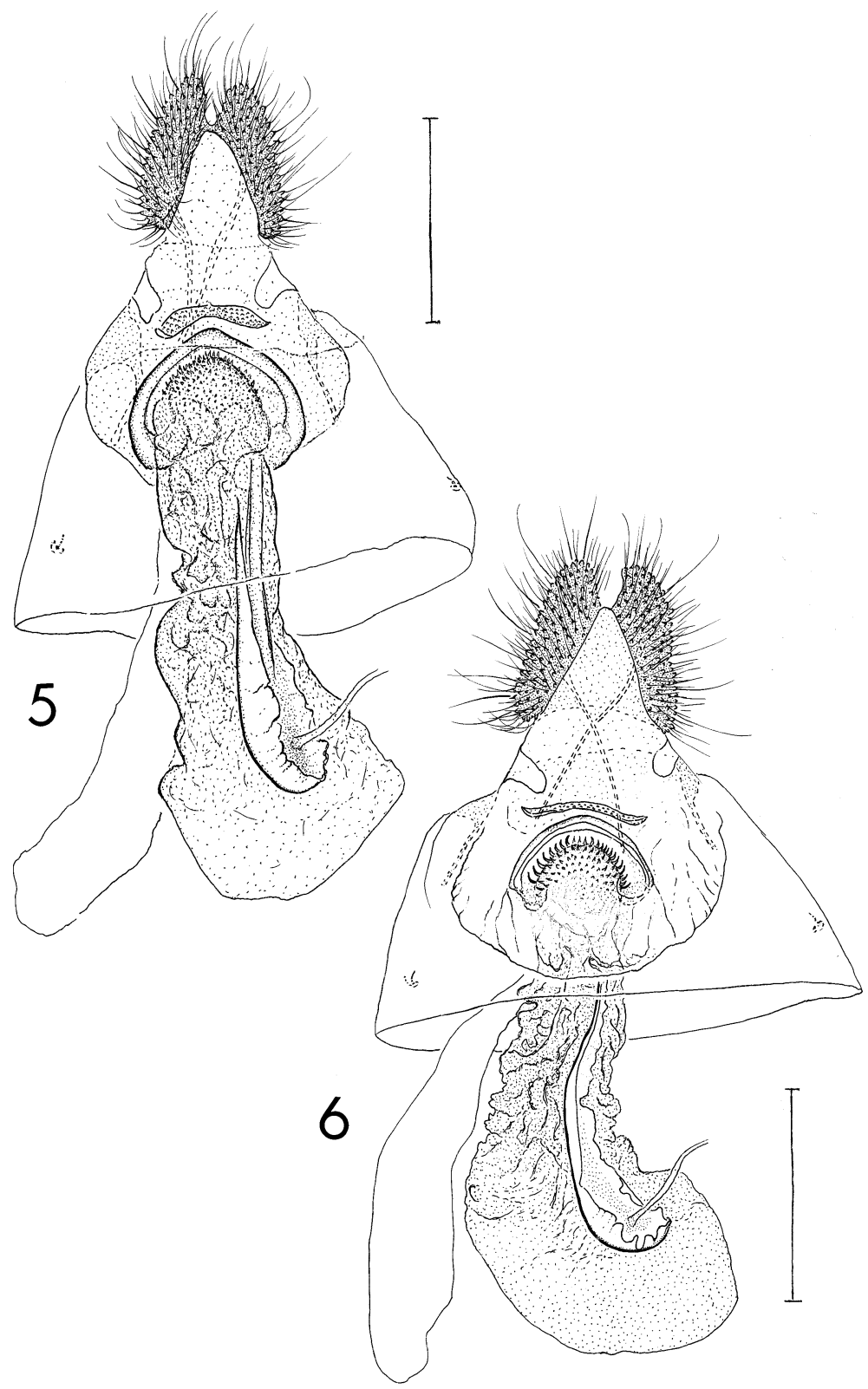

Figs. 5-6. Female genitalia of Netechma. 5. N. similis; 6. N. caesiata (scale bars $=0.5$ $\mathrm{mm}$ ). 
surrounding the ostium and by the curvature of the unusual troughlike signum (see Figs. 5-6).

Description. Male. Head: Lower frons pale tan to buff; upper frons buff. Labial palpus whitish tan to buff mesally, buff with sparse pale red-brown scales laterally. Thorax: Buff; tegula pale steel gray. Forewing (Fig. 2) length $4.9-5.5 \mathrm{~mm}(\overline{\mathrm{x}}=5.2$ $\mathrm{mm} ; \mathrm{N}=5$ ). Ground color buff, basal two-fifths overscaled with steel gray, costa with distinct dark red-brown markings, frequently extending toward dorsum; broad transverse medial band, comprised variously of lead-gray, brown, red-brown, and yellow-brown areas, extending from costa to dorsum, ca. 0.4 to 0.7 distance from base to apex. Fringe buff. Venation simple, with all veins present and separate; chorda represented by a trace near distal end of DC; $\mathrm{CuP}$ present only at base. Hindwing white, overscaled with pale gray-brown. Venation with Rs and M1 stalked ca. 0.35 distance from cell to wing margin; $\mathrm{M} 3$ and $\mathrm{CuA} 1$ short-stalked; CuP present. Abdomen: Buff, darker posteriorly. Genitalia as in Fig. 4 (drawn from JWB slide 1009; 2 preparations examined). Uncus long, extremely slender, curved in distal onehalf. Socius moderately broad, densely scaled. Gnathos slender, weak. Transtilla an arched bridge, with sparse, slender, spine-like teeth. Valva moderately long, broadened distally, with large, rounded apex; a large, complex process from basal twothirds of costal region, with a free, spiny, apically digitate process and a sclerotized band along costa. Juxta a simple plate. Aedeagus broad, short, gently curved; distal portion with slender, attenuate spine; cornuti absent, vesica denticulate.

Female. Head, Thorax: Essentially as described for male. Forewing length 6.1$6.3 \mathrm{~mm}(\overline{\mathrm{x}}=6.2 \mathrm{~mm} ; \mathrm{N}=2$ ). Abdomen: Genitalia as in Fig. 5 (drawn from JWB slide $1010 ; 2$ preparations examined). Papillae anales unmodified; sterigma with a narrow transverse sclerotized band posterad of ostium; ostium surrounded by inverted u-shaped membranous region; area immediately around ostium with a large, complex, rounded, spiny lobe. Ductus bursae extremely broad, only slightly widening at corpus bursae. Corpus bursae oblong, spiculate, with long, straight, trough-like signum, slightly curled in anterior one-fifth, with ductus seminalis originating from near middle of curved anterior portion of signum.

Types. Holotype, ô, COSTA RICA, Puntarenas Prov., Est. Altamira, A. C. Amistad, Buenos Aires, 1,150-1,400 m, XII.1994 (M. Segura, INBio). Paratypes: 40 ô, 2 우. COSTA RICA, Cartago Prov.: A. C. Amistad, Monumento Nacional Guayabo, 1,100 m, 1 ô, VII.1994 (G. Fonseca, INBio). Puntarenas Prov.: Cerro Biolley, A. C. Amistad, Sector Altamira, La Amistad, 1,800 m, 10ิ, 1 ㅇ, I.1994 (R. Delgado, INBio); Fca. Cafrosa, Est. Las Mellizas, P. N. Amistad, 1,300 m, 10, X.1990, 1 के, III.1991 (M. Ramirez \& G. Mora, INBio), 1ㅇ, V. 1991 (M. Ramirez, INBio).

Discussion. $N$. similis is known only from Puntarenas and Cartago provinces, Costa Rica, from 1,100-1,400 m elevation. Adults have been collected in January, March, May, July, and December. The early stages are unknown.

Etymology. The species name is derived from its superficial similarity to members of the genus Icteralaria.

\section{Netechma caesiata (Clarke), new combination}

Figs. 1, 3, 6

Cochylis caesiata Clarke, 1968: 18; Razowski, 1994: 295.

"Cochylis" caesiata: Powell et al., 1995: 142. 
Diagnosis. Netechma caesiata can be distinguished from $N$. similis by characters discussed in the diagnosis of $N$. similis above. In particular, the rounded spiny region at the ostium of $N$. caesiata has slightly larger spines and a shorter membranous inverted u-shaped region, and the troughlike signum is slightly more undulate (Figs. $5-6)$.

Redescription. Male. Unknown.

Female. Head: Lower frons pale tan to buff; upper frons buff. Labial palpus pale tan to buff mesally, buff, with sparse pale red-brown scales laterally. Thorax: Buff; tegula pale steel gray. Forewing (Figs. 1, 3) length 5.1-6.3 $\mathrm{mm}(\overline{\mathrm{x}}=5.9 \mathrm{~mm} ; \mathrm{N}=$ 7). Ground color buff, basal two-fifths lightly overscaled with steel gray; broad transverse band, comprised variously of lead-gray, brown, red-brown, and yellowbrown areas, extending from costa to dorsum, ca. 0.4 to 0.7 distance from base to apex. Fringe buff. Venation (Fig. 3) as described for N. similis. Hindwing: White, overscaled with pale gray-brown. Venation (Fig. 3) as in N. similis. Abdomen: Buff, darker posteriorly. Genitalia as in Fig. 6 (drawn from USNM slide 89265; 3 preparations examined). Papillae anales somewhat slipper-shaped, unmodified; sterigma with a narrow transverse sclerotized band posterad of ostium, narrower than that of $N$. similis; ostium surrounded by inverted u-shaped membranous region, less extensive than that of $N$. similis; area immediately around ostium with a large, complex, rounded, spiny lobe. Ductus bursae extremely broad, only slightly widening to corpus bursae. Corpus bursae oblong, spiculate, with long, slightly undulate, troughlike signum, slightly curled in anterior one-fifth, with ductus seminalis originating from near middle of curved anterior portion of signum.

Types. Holotype, $q$, VENEZUELA, Aragua, Rancho Grande, 1,100 m, 1623.X.1966 (S. S. \& W. D. Duckworth, USNM). Paratypes: VENEZUELA, Aragua: $2 ㅇ$, same locality as holotype, 11-19.I.1966 (S. S. \& W. D. Duckworth, USNM). Additional Specimens Examined. VENEZUELA, Aragua: Rancho Grande, 1,100 m, 2 우, 11-15.I.1966, 1 , 1-5.XI.1966 (S. S. \& W. D. Duckworth, USNM), 1 ㅇ, 17.VIII.1967, 2 q $~$, 8-14.VIII.1967, 1 9 , 15-21.VIII.1967, 2 ㅇ , 22-31.VIII.1967 (R. W. Poole, USNM), 1, 10-21.II.1969 (Duckworth \& Dietz, USNM), 1 $9,17-$ 20.I.1978 (J. B. Heppner, USNM).

Discussion. Netechma caesiata is known only from Rancho Grande, Venezuela, in cloud forest habitat at 1,100 m elevation. Adults have been collected (at blacklight) in January, February, August, and November. Nothing is known of the early stages.

This species was described from 3 females from Rancho Grande, Venezuela; we discovered 11 additional specimens-all females and all from Rancho Grande. Although Razowski (1994) indicated that caesiata most probably was transferable to Euliini, Powell et al. (1995) treated the species as "Cochylis" (uncertain generic placement within Cochylini). The female genitalia demonstrate that $N$. caesiata is congeneric with $N$. similis and $N$. technema, the latter the type species of the genus Netechma.

\section{DISCUSSION}

Netechma belongs to a group of genera in Euliini that are characterized by one or more sparganothine-like features of the male genitalia, including a spiny transtilla, 
a long, slender, hooklike uncus, and densely scaled socii. Apparently related genera include Icteralaria, Paraptila Meyrick, Terinebrica Razowski, and Atepa Razowski.

As presently defined (Razowski, 1999), Netechma may represent a paraphyletic or polyphyletic assemblage of species, many of which are known only from a single sex or even a single specimen. Razowski (1999) treated 27 species in his recent review of genus, transferring to the group 9 species described by Meyrick that formerly defied confident generic assignment (i.e., "Eulia" of Powell et al., 1995) and 6 species formerly assigned to Icteralaria (Razowski 1997). While this initial action brings together a variety of species with similar genitalia, additional analyses of Netechma and Icteralaria are needed to identify monophyletic lineages and clarify the relationship between the two genera.

\section{ACKNOWLEDGMENTS}

We thank Eugenie Phillips for the loan of specimens from INBio. Jerry Powell, University of California, Berkeley, and Kevin Tuck, The Natural History Museum, London provided specimens of related genera for comparison. We thank Jozef Razowski for his opinion regarding the validity of the new species. We thank the following for helpful comments on the manuscript: Steven Lingafelter and David Smith, USDA, Systematic Entomology Laboratory, National Museum of Natural History, Washington, D.C.; Kevin Tuck, The Natural History Museum, London, England; and Richard Brown, Mississippi State University, Mississippi, U.S.A. Field work in Costa Rica was facilitated by an NSF-funded project, the Arthropods of La Selva, under the leadership of John Longino, Evergreen State College, Olympia, Washington. Visits to INBio were funded by that institution.

\section{LITERATURE CITED}

Brown, J. W. 1990. Taxonomic distribution and phylogenetic significance of the male foreleg hairpencil in the Tortricinae (Lepidoptera: Tortricidae). Entomol. News 101:109-116.

Brown, J. W. 1998. Description of Strophotina, new genus, from Central and South America (Lepidoptera: Tortricidae). Proc. Entomol. Soc. Wash. 100:43-49.

Brown, J. W. 1999a. A new species of Pseudocomotis from Costa Rica (Lepidoptera: Torticidae: Chlidanotinae), with the first reported female. Trop. Lepid. 9:55-57.

Brown, J. W. 1999b. Dimorphopalpa, a new genus of tortricid moths from Central and South America (Lepidoptera: Tortricidae: Euliini). Pan-Pac. Entomol. 75:82-93.

Brown, J. W. 1999c. A new euliine genus from Costa Rica and Venezuela (Lepidoptera: Tortricidae). J. New York Entomol. Soc. 106:177-184.

Brown, J. W. and J. A. Powell. 2000. Systematics of Anopina Obraztsov (Lepidoptera: Tortricidae: Euliini). Univ. Calif. Publ. Entomol. 120. 128 pp. + figs.

Clarke, J. F. G. 1958. Catalogue of the type specimens of Microlepidoptera in the British Museum (Natural History) described by Edward Meyrick. Vol. 3. Published by the Trustees of the British Museum, London, $599 \mathrm{pp}$.

Clarke, J. F. G. 1968. Neotropical Microlepidoptera, XVII. Notes and new species of Phaloniidae. Proc. U.S. Natl. Mus. 125(3660):1-58.

Horak, M. 1984. Assessment of taxonomically significant structures in Tortricinae (Lep., Tortricidae). Mit. Schweiz. Entomol. Gesel. 57:3-64.

Powell, J. A., J. Razowski and J. W. Brown. 1995. Tortricidae: Tortricinae, Chlidanotinae, pp. 138-151 in J. B. Heppner (ed.), Atlas of Neotropical Lepidoptera, Checklist Part II: Hyblaeoidea-Pyraloidea-Tortricoidea. Association for Tropical Lepidoptera, Scientific Publishers, Gainesville, FL. 
Razowski, J. 1990. Cochylini (Lepidoptera: Tortricidae) from Costa Rica. Misc. Zool. 14:85103.

Razowski, J. 1992. On some peculiar Neotropical torticine genera (Lepidoptera: Tortricidae). SHILAP Revta. Lepid. 18:209-215.

Razowski, J. 1997. Euliini (Lepidoptera: Tortricidae) of Peru with description of new taxa and list of the New World genera. Acta Zool. Cracov. 40:79-105.

Razowski, J. 1994. Synopsis of the Neotropical Cochylini (Lepidoptera: Tortricidae). Acta Zool. Cracov. 37:121-320.

Razowski, 1999. Synopsis of species of Icteralaria Razowski and Netechma Razowski (Lepidoptera: Tortricidae) with description of new taxa. Polskie Pismo Entomol. 68:91-106.

Received 1 May 2002; accepted 13 July 2002. 